\title{
Despre ură și tipologia inadaptatului la Dostoievski și Salinger
}

\author{
Călin-Horia Bârleanu ${ }^{\circledR *}$ \\ Facultatea de Litere și Științe ale Comunicării, Universitatea „Ștefan cel Mare”, Str. Universității 13, 720229 Suceava, România
}

\begin{abstract}
Despre articol
Istoric:

Primit 18 februarie 2021

Acceptat 11 martie 2021

Publicat 18 august 2021

Cuvinte-cheie:

psihanaliză

adolescență

dispreț

pulsiune de moarte

Rezumat

Ca parte a pulsiunii de moarte, ura, atît de vehiculată la nivelul literaturii universale, ca stare naturală pentru unele personaje, a generat adevărate capodopere ale spiritului creator, permanent preocupat de metamorfoză și, uneori, chiar de ascensiune. Malignă sau sub formă justificată social, benignă, ura și toate formele ei de manifestare generează atitudini care caracterizează un alt concept fundamental pentru literatura lui Dostoievski - antieroul. Cu trăsături specifice, pe care le putem regăsi în toată literatura de după marele scriitor rus, personajul care plătește tribut urii se retrage din fața lumii, alimentîndu-şi astfel alienarea superficială.
\end{abstract}

\section{Introducere}

Dimensiunile postmodernismului american pot fi înțelese cu adevărat doar dacă se introduce în analiză impactul pe care l-a jucat Dostoievski în cîmpul întregii literaturi americane. De la figurile animate de arhetipuri și pînă la acțiunile simbolice, specifice scriiturii dostoievskiene, pot fi observate, în spațiul cultural american, și nu numai, preluări punctuale sau dezvoltări ale unor cadre și personaje asupra cărora se proiectează autenticitatea în construcția psihologică. Ca nici un alt scriitor, Dostoievski stăpînește tehnica necesară mimetismului, construind, de pildă, sentimentul timpului și al aşteptării, prin intermediul experienței care i-a marcat existența, al falsei condamnări la moarte. Exemplele unde scriitorul rus merge în creație pe calea din exterior spre filtrul artistic, pot fi, ca număr, egalate de cele în care traseul pornește din interior, pe calea instrospecției. Primul roman și cel care i-a adus poate și cea mai mare dezamăgire, Dublul, reprezintă o dovadă destul de clară, dincolo de filiația pe care Dostoievski a recunoscut-o faţă de Gogol, a profunzimii viziunii celui care realizează un tratat al scindării interioare.

Tipologiile psihologice dostoievskiene rămîn, pentru cadrul general al literaturii universale, repere care au generat o influență practic imposibil de cuantificat. Gîndindu-ne doar la Kafka, Faulkner, Hemingway sau, cronologic mai aproape de noi, Salinger, Ellis sau Pamuk, putem identifica acțiuni simbolice și prototipuri umane peste care se pot suprapune oricînd personajele proiectate de scriitorul rus. Pe linia Gogol - Dostoievski, „metafora obsedantă” care pune în centru alienarea specifică grupului format din funcționari poate fi identificată, ca un refren, în toată literatura universală de după cei doi scriitori. $\mathrm{Nu}$ doar la Kafka, ci și în literatura lui Bret Easton Ellis, care aproape că pune un semn de echivalență între grup și alienare, găsim cadrul colectiv, atît de favorabil scindării interioare. Fie că ne referim la Glamorama sau la American psycho (două dintre cele mai apreciate romane scrise de Easton Ellis), acolo unde apare o aglomerare urbană sau pur și simplu socială, specifică oricărui cadru modern și postmodern, sentimentul înstrăinării și al pierderii identității se construiește aproape în mod reflex.

Ca urmare, îndepărtarea nu reprezintă o acțiune simbolică destinată exclusiv scenariului în care protagonistul încearcă să se integreze sau face parte dintr-un anumit grup, cu atît mai mult, cu cît germenii alienării există în egală măsură în fiecare individ. Fie că face parte dintr-un grup select, frumos și dezirabil din exterior, al modei și atenției pentru proproiul aspect, așa cum propune Ellis în Glamorama, sau din

\footnotetext{
*Adresă de corespondență: calin.barleanu@gmail.com.
} 
Călin-Horia Bârleanu

cel al tinerilor de succes, după cum își proiectează romanul American psycho, aglomerat de femei și bărbați realizați și la apogeul unei cariere pentru care cadrul financiar nu reprezintă nici măcar subiect de discuție, personajul central dovedește o elasticitate morală ieșită din comun, împrumutînd din grupul căruia îi aparține cele mai importante trăsături caracterizate, de obicei, prin superficialitate. Pe linia pornită de Gogol și Dostoievski, dificultățile întîmpinate de tipologiile atinse de marca destinului tragic, dintre care menționăm doar sentimentul implacabil al ratării și al alienării, un ghinion care în literatura rusă este, de cele mai multe ori corelat cu alegerile neinspirate ale celor care trec printr-un adevărat travaliu de integrare socială, sînt similare cu cele propuse de literatura universală de după ei.

Exemplar însă este personajul lui J.D. Salinger, Holden Caulfield, din cel mai cunoscut roman al scriitorului american, De veghe în lanul de secară. Se păstrează componenta socială, în registrul alienării, în cele mai mici detalii, pentru că adolescentul Holden, care și rememorează întîmplările din roman, tocmai este exmatriculat, nu pentru prima dată, de la un prestigios colegiu. Psihologia adolescentului, care oferă greutate romanului american, este și cea care proiectează protagonistul într-o tipologie universală, frustrată şi incapabilă cronic de a obține sentimentul de mulțumire în raport social sau la nivelul propriilor reprezentări și aspirații. Pe această direcție psihologică, înaintea lui Salinger, Dostoievski a reușit adevărate incursiuni spre modele comportamentale similare. De la Arkadi Makarovici Dolgoruki, din Adolescentul și pînă la tinerii Aleoșa Karamazov și Smerdeakov, din Frații Karamazov, scriitorul rus a păstrat o componentă latentă în proiectarea personajelor tinere: o lipsă structurală de constanță, sub forma unei căutări sau explorări, atît la nivel mental, ideologic, cît și, concret, în planul fizic, al corporalității.

Aici, se cuvine să observăm că personajele evocate par animate de o frustrare imposibil de acoperit și care nu poate fi legată de un scenariu fix, concret, generator al nemulțumirii care se manifestă de multe ori conflictual. Cu toate că traducerea în limba română a textului lui Salinger nu păstrează nuanța psihologică de tip conflictual, a protagonistului, în limba engleză Salinger folosește cuvîntul hate și derivatele lui de peste cincizeci de ori, de obicei în raport cu Holden și cu felul în care acesta proiectează spre lume, oameni, situații diferite ori singura trăire disponibilă. Nu avem, aşadar, în vedere, un simplu dispreț pentru scenariile incomode sau necunoscute, ci o ură care este perfect ancorată psihologiei adolescentului. Ea este evocată mai ales din perspectivă lingvistică, superficial aşadar, de un personaj care își dorește să fie perceput ca fiind mai mare decît este, acceptat și apreciat pentru o valoare pe care încă nu a reușit să o confirme, în ciuda speranțelor și așteptărilor sale. Cuvîntul și trăirea se referă la ură, ca emoție esențială în cîmpul pulsiunii de moarte, dar acțiunile eroului, cu veritabile trăsături specifice antieroului, arată, de fapt, că adolescentul marcat de frustrare nu face decît să aleagă un cuvînt cu rezonanțe dure, ură, nu însă și conținutul acestuia.

\section{Un tip psihologic universal}

Instabilitatea psihologică a lui Arkadi, gata oricind să-și schimbe radical credințele și idealurile, poate fi identificată și în felul în care sînt proiectați Aleoșa și Smerdeakov captivi într-o mișcare de pendulare permanentă. Mezinul Karamazov se apropie de pierderea credinței cînd fuge din mănăstire, după ce trupul starețului Zosima, imagine a paternității, intră într-un proces de descompunere, incompatibil pentru tînăr cu imaginarul și reprezentările religioase construite în relație cu preotul şi duhovnicul. Mai mult, între viața la mănăstire și viața socială, tînărul Aleoșa se simte, în cele mai multe dintre paginile romanului, atras de tot ceea ce presupune dinamica de grup. Între copii, de pildă, la fel ca Mîșkin, o altă tipologie de tînăr labil (cu toate că eroul din Idiotul este construit mai cu seamă printr-o fragilitate fizică ieșită din comun), Aleoșa se lasă ancorat de evenimente care, invariabil, duc spre familia sa și spre corupția morală.

Acest tipar dostoievskian este adaptat perfect de Salinger în privința lui Holden, la fel de grăbit în schimbarea cadrelor interioare și, mai ales, atras de ideea salvării universului infantil. Aleoșa Karamazov, mai degrabă decît Arkadi Andreevici Macarovici, din Adolescentul, alături de figura prințului Mîșkin par să reprezinte modele veritabile pentru tipologia celui care trăiește în psihologia jungiană a umbrei, atins de un veritabil destin tragic. Aici, vom evidenția felul în care protagonistul din Idiotul își amintește perioada 
petrecută în străinătate, mai cu seamă în compania copiilor: „,..îmi plăcea să mă aflu în mijlocul lor, și aşa îmi petrecui între ei toți cei patru ani cît am stat acolo. $\mathrm{N}$-aveam nevoie de nimic altceva”, aşa cum Aleoșa este descris, în nenumărate pagini, în mijlocul copiilor, coordonîndu-i, regăsindu-se în ideologia lor simplă și necontaminată de meschinăriile specifice psihologiei de grup (Dostoievski, 1962, p. 110). Mai mult, finalul romanului Frații Karamazov, dincolo de moartea micului Iliușa, se centrează atît pe arhetipul pîinii, cu toate valențele sale de regenerare, cît și pe întregul univers infantil, cu naivitatea-i specifică, caracterizată de o vitalitate imposibil de înfrînt. Ultima secvență a romanului este grăitoare în acest sens: „- Mereu vom merge așa, toată viața, mînă în mînă! Urra, trăiască Aleoșa Karamazov! strigă din nou Kolea, și glasurile tuturor copiilor se îngemănară într-o izbucnire de entuziasm" (Dostoievski, 1993, p. 676).

Imaginea mezinului Karamazov, înconjurat de copii, realimentîndu-şi prin prezența lor rezervorul necesar unei trăiri veritabile, în absența reflexelor specifice individului obișnuit cu „jocurile” și intrigile grupului social, dar și ghidîndu-i pe cei mici spre calea creștină de existență, preocupat așadar de viitorul micro- dar și macro-cosmosului său, poate fi intuită în spatele fanteziei lui Holden, proiectat de Salinger ca parte a unei tipologii frustrate, fără loc, animate de o căutare cu ecouri atît interioare, cît și în afara granițelor propriului eu. Întrebat ce i-ar place să facă, la maturitate, cu stilu-i inconfundabil, niciodată serios și încă instabil în privința ideologiei, protagonistul aproape visează cu ochii deschiși o adevărată metaforă, poate una dintre cele mai frumoase ale întregului postmodernism american:

,...în mintea mea am văzut o mulţime de copii mititei jucînd un joc în lanul întins de secară. Mii de copii - și nimeni în jur, adică nici un om mare, în afară de mine. Și eu stau la marginea unei prăpastii amețitoare. Și știi ce fac? Prind copiii să nu cadă în prăpastie. Vreau să spun, cînd aleargă și nu se uită unde merg, trebuie să le ies în cale și să-i prind. Asta aș face toată ziua. Aș sta de veghe în lanul de secară [...]. E singurul lucru care m-ar tenta” (Salinger, 2001, p. 210).

Antichitatea a fost cea care a pus, de fapt, urîtul și dismorficul într-un context plin de semnificații, sugerînd abisul care se ascunde chiar și în cele mai mlăștinoase ape, atît de diferite de cele limpezi și care satisfac rigorile estetice. În sălbăticia lui Enkidu, din Epopeea lui Ghilgameș, sau în metamorfoza imaginată de Apuleius, în Măgarul de aur, putem identifica forme similare de contaminare a orizontului uman, prin felul în care se suprapune peste el ceva din registrul animal, aparent sălbatic și tot aparent, incompatibil cu tot ceea ce înseamnă cultură și civilizație. Iată, de pildă, în ce termeni este descris Enkidu, plămădit de zei din lut pentru a-i deveni egal lui Ghilgameș și, mai ales, pentru a contribui la echilibrarea prea puternicului rege. Lutul aruncat într-un spațiu sălbatic prinde o formă specifică locului în care ajunge: „Trupul său era butucănos, purta plete lungi asemenea femeii [...] era acoperit cu un păr stufos [...]. Nu știa nimic despre oameni, nu avea habar de lumea orașelor și a satelor” (Daniel \& Acsan, 1981).

Nepriceperea antică a lui Enkidu găsește în tipologiile moderne, proiectate de scriitori, forme similare. Marcaţi prin defecte sau prin particularități deosebite, adesea atinși de un orizont maladiv prezent constant în viaţa protagoniștilor, au abilități sociale reduse, adesea inexistente. În acest context, vom aminti că Prințul Mîșkin nu reușește să înțeleagă subtilitățile specifice comunicării de grup, motiv pentru care este și stereotipizat și considerat, pentru permanenta raportare la adevăruri incomode (trăsătură care îl și pune în proximitatea arhetipului de tip trickster), ca fiind un idiot, iar Arkadi își construiește planuri mari și se răzgîndește la fel de repede, animat de pulsiuni care denotă imaturitate și superficialitate, în vreme ce, mai tîrziu, Holden, al lui Salinger, pare blocat în tipologia unui trickster al cărui destin tragic este de a dezamăgi în mod repetat pe toți cei care au așteptări îndreptate spre el. Prin urmare, relațiile sociale par să fie, atît pentru Dostoievski cît și pentru Salinger, adevărata măsură a alienării eroilor.

Din primele clipe, așadar, arta și, mai cu seamă, literatura, a intuit că în formele mai puțin acceptabile, din perspectivă estetică, se ascunde un potențial la fel de generos precum cel specific personajelor și simbolurilor valorizate pozitiv. În rău și urît pare să fi existat, dintotdeauna, o cale directă spre catharsis și, dincolo de el, obligația de a proiecta lumii figuri și scenarii recognoscibile, experimentate intim de cei 
mai mulți dintre receptori cu mult înaintea contactului cu opera. Pe această cale, deschisă instinctual de spiritul artistic universal, explorator, Dostoievski a construit marele său monument, dedicat antieroului. Răul alăturat urîtului, iar uneori asociat frumosului, a reprezentat pentru literatura scriitorului rus un reper imposibil de ignorat. Înseși realitățile lumii în care a trăit și din care a experimentat obiectiv, prin intermediul presei, sau intim, prin atît de intensele evenimente prin care a trecut (falsa condamnare la moarte, jocul la ruletă și perspectiva reală a incapacității de a-și mai susţine existența, financiar, decesul unui copil), l-au pus pe Dostoievski în proximitatea unui imaginar morbid, generator al unor scenarii din care antieroul nu poate lipsi. Pe lîngă celelalte romane, Adolescentul (Dostoievski, 2019) pendulează, pînă astăzi, între cele două dimensiuni ale întregii scriituri dostoievskiene: capodoperă sau eșec.

$\mathrm{Cu}$ personajul său central, Arkadi Andreevici Makorovici, sau mai scurt, Dolgoruki, romanul se construiește în jurul imaginii paternității, pe care tânărul o caută neobosit, frustrat de distanța imposibil de anulat și care îl separă de Versilov: „Trebuie să mărturisesc că tocmai în perioada aceea eram mai nedumerit ca oricînd în privința lui. De altfel, asta m-a și determinat să scriu această poveste” (Dostoievski, 2019, p. 410). Tipologia psihologică a bastardului este exemplar proiectată de scriitor, în relație cu ceea ce Marthe Robert observa, pe bună dreptate, în întreaga operă dostoievskiană. Cele două tipuri de personaje, care generează în mod reflex două direcții diferite în roman, a eroului și a bastardului (Robert, 1983, p. 80), pot fi identificate alternativ la nivelul scriiturii dostoievskiene, cu simboluri și acțiuni simbolice specifice. Tînărul Arkadi, marcat de titulatura de bastard, în care se și refugiază adesea, are un ecou în felul în care Holden reacționează social, în grupurile din care se străduie să facă parte. Fără a face parte din tipologia bastardului, aşa cum fac parte Arkadi sau Smerdeakov, adolescentul lui Salinger umblă printre ceilalți oameni, vîrstnici și tineri, fiind complet diferit de ei și simțindu-se la fel, ca alteritate.

Preocuparea pentru relațiile sociale pare să existe în egală măsură la cei doi protagoniști, Arkadi și Holden, însă dimensiunile eșecului evocă incapacitatea celor doi de a lega și chiar de a întreține legături cu ceilalți. Animat de trăiri specifice adolescenților, în conflictual cu cei care-l iubesc necondiționat, Arkadi pare incapabil de a fi constant în alegerile sau rezoluțiile sale. Preocupat de o „idee”, ascunsă și totuși intuită cu ușurință de cei care sînt dispuși să-l înțeleagă pe superficialul adolescent, dedicat ei întru totul, o abandonează cu o rapiditate care evocă aceeași tipologie a bastardului, gata să se adapteze oricînd, nu în funcție de idealurile sale, $c i$ în raport cu stimulii exteriori și dezideratele de grup.

Pe de altă parte, Holden, ca ecou îndepărtat al aceleiași tipologii, manifestă aceleași dificultăți în stabilirea relațiilor sociale. Inconștient, ca parte a figurii de tip trickster, tînărul american, refuză orice nu îi este pe plac, indiferent la consecințe. Ales căpitan al echipei de scrimă, „căzuse beleaua pe mine”, pierde tot echipamentul în drum, cu echipa, spre o competiție: „....întîlnirea n-a mai avut loc. Am uitat toate floretele, tot echipamentul și toate alea în păcătosul de metrou” (Salinger, 2001, p. 8). Aceeași superficialitate poate fi observată și în cazul tînărului Arkadi, incapabil să intuiască pericolul de a rămîne fără scrisoarea compromițătoare cusută în căptuș̦eala paltonului său. Pare mînat de un impuls irațional, adesea de a vorbi, dezvăluind liber și fără nici o rezervă, informații sensibile, inclusiv pentru el, alteori de a consuma alcool, iar în alte situații de a reacționa disproporționat, fără o abilitate clară aşadar de a-și adapta atitudinea sau răspunsurile la atitudinile celorlalți, sugereînd, astfel, atît arhetipul de tip trickster, blocat într-o fidelitate absolută faţă de conceptul de adevăr (aşa cum este el perceput și construit de adolescent), cît și în aceeași inabilitate de a înţelege lumea, cu toate meschinăriile ei. Nu neatenţia lui Arkadi duce la furtul scrisorii, acțiune și intrigă oricum mult sub specificul tematic și metaforic dostoievskian, ci felul său unic de a percepe realitățile și oamenii care le construiesc. Adolescentul însetat de acceptare socială, și frustrat pe întreg parcursul romanului de felul în care este perceput, „se purta cu mine de parcă aș fi fost un băiețandru naiv - atitudine care mă scotea din sărite” (Dostoievski, 2019, p. 23) este supusul propriului inconștient, după cum Holden reacționează, la fel, frapant și în opoziție flagrantă cu ceea ce se așteaptă de la el.

Precizăm că, atunci cînd ne-am referit la conceptul de „destin tragic de tip trickster”, evident, cu referire la personajele Arkadi și Holden, am urmărit tocmai felul în care protagoniștii $n u$ se exclud din scenariile în care par să dezamăgească, neîncadrîndu-se într-un tipar comportamental sau ideologic. Așadar, nu ei sînt 
trădați, doar părinții, de pildă, și putem discuta inclusiv despre o ratare percepută la nivel personal, intim, de cei care se simt purtați de evenimente și privați complet de voință. Ca urmare, elemente subtile, care pot fi regăsite generos în poetica dublului, la Dostoievski, pot fi identificate în Adolescentul, sugerînd tocmai o anumită distanță între erou și acțiunile sale, de multe ori neasumate. Așa cum Goleadkin își propune să acționeze într-un anumit fel, doar pentru a reacționa în sens opus, imediat, Arkadi este, în unele scene, un călător dus de reflexele sale inconștiente: „Nu știu dacă m-am dus la Tatiana Pavlovna fiindcă îmi venea să mă spovedesc, sau să mă laud, să mă iau la ceartă, sau să plîng, știu însă că m-am trezit urcînd scările" (Dostoievski, 2019, p. 153).

Frica nejustificată, din care Dostoievski a făcut un adevărat monument literar, plasînd angoasa în centrul trăirilor și proceselor interioare ale eroilor săi, poate fi observată la personajul lui Salinger, întărind astfel apartenența lui Holden la tipologia antieroului. O bătaie neașteptată în ușă va fi, în imaginarul dostoievskian, permanent asociată fricii: „Eram destul de speriat. Sînt foarte laș cînd e vorba de situații d-astea" (Salinger, 2001, p. 124).

Se cuvine să amintim, aici, și că psihanaliza a fost cea care a arătat, prin bogata operă freudiană, că iraționalul și, în general, ceea ce nu poate fi justificat, în relație cu un gînd sau cu o trăire, are originea în interiorul individului. Filonul comun al celor două opere, Adolescentul și De veghe în lanul de secară, rămîne ancorat de imaginarul morbid, specific corupției morale. Arkadi se lasă purtat de vocea lumii pe care inițial încearcă să o respingă, devenind din ce în ce mai mult parte dintr-un grup uman meschin și dominat de imperativul lui a avea, după cum Holden, ca ecou îndepărtat al tipologiei, este parte a aceluiaşi sistem corupt din care încearcă să iasă. În definitiv, felul în care tînărul se refugiază în imaginar, devenind erou care salvează copiii de la căderea în prăpastie, sugerează aceeaşi direcție simbolică.

Cele două personaje se disting, totuşi, în largul orizont al literaturii universale, prin graba cu care proiectează asupra relațiilor sociale sentimente morbide, în special ceea ce consideră că ar fi ură. Asumată ca atare, sau adesea mascată pentru a ilustra sau doar din credința că ura este cea mai potrivită pentru un anumit scenariu, Arkadi, în ciuda lipsei sale de experiență în viață, se hazardează uneori și concluzionează că „am urît toată viața asemenea tărășenii” (Dostoievski, 2019, p. 12). Mai departe, adolescentul își asumă, într-un registru pueril, o formă de indiferență față de sexul opus, față de care nu poate rămîne fidel oricum: „E drept că nu știu nimic despre femei și nici nu vreau să știu, fiindcă am jurat să nu mă sinchisesc de ele cît voi trăi”" (Dostoievski, 2019, p. 13). Mai mult, gata să-şi asume idei sau o ideologie care are în centru o trăire sau sentimente morbide, Arkadi construiește adevărate scenarii care să îi susțină credințele superficiale. Fără să și afirme că urăște femeile elegante, tînărul se angajează în adevărate demonstrații pasionale:

„Vezi cîte o doamnă mergînd pe bulevard, foșnind dintr-o trenă de doi coți, măturînd praful de pe uliță; dacă te nimerești în spatele ei, nu-ți rămîne decît s-o iei la fugă ca să o întreci sau să sari în lături [...]. Unde mai pui că rochia doamnei e de mătase [...] în timp ce soțul nu cîștigă la senat decît cinci sute de ruble pe an [...]. Iată de ce sînt atît de scîrbit, de ce le disprețuiesc și le ocărăsc în gura mare" (Dostoievski, 2019, p. 32).

Observăm, așadar, că Dostoievski reușește, pe căile cele mai directe și mai degrabă puțin specifice literaturii sale, să asocieze tipologia adolescentului unor trăsături esențiale cum ar fi inconstanța, superficialitatea, impulsivitatea. De pildă, disprețul lui Arkadi pentru femeile îmbrăcate după o anumită modă, atît de aspru judecate, dispare subit, în contextul unui cîștig financiar. El se grăbește să ajute, cît se poate de gentil: „lam întins cu o mînă doamnei, în timp ce cu cealaltă îmi scoteam pălăria” (Dostoievski, 2019, p. 49). Dar vom observa că este genul de femeie despre care vorbește, cu un alt prilej, aproape cu ură: „,...din casă ieși o doamnă elegantă, tînără, frumoasă, bogată, îmbrăcată numai în mătase și catifea, cu o trenă de doi coți” (p. 49).

Dar și Holden Caulfield este proiectat cu atenție pentru aceleaşi repere interioare care plasează eroul într-o postură specifică faţă de orizontul feminin. Adolescentul american, de pildă, manifestă același tip de dispreț, care maschează incertitudine și nesiguranță: „Nenorocirea e că mi-e milă de ele. Adică majoritatea 
fetelor sînt atît de proaste și de neajutorate!" (Salinger, 2001, p. 114). Eroul lui Salinger, mai mult decît cel dostoievskian, și specific ideologiei literare postmoderniste, este asociat unor reflexe psihologice care au și o oarecare detentă simbolică, sugerînd trăiri și sentimente puțin vizibile ochiului neobișnuit cu sensul latent și manifest al existenței. Față în față cu o prostituată, despre care vorbește cu liftierul unui hotel și pe care o acceptă, Holden mai degrabă amorțește senzorial: „Pe măsură ce trecea timpul, deveneam tot mai indiferent" (p. 116). Observînd-o pe fata care îi intră în cameră, toate reacțiile și sentimentele protagonistului sînt proiectate asupra ei: „s-a aşezat picior peste picior şi a reînceput să-și bîțîie piciorul. Era foarte nervoasă pentru o prostituată. Zău că da. Cred că era nervoasă pentru că era îngrozitor de tînără. Cred că avea vîrsta mea” (p. 116). Altfel spus, adolescentul atribuie femeii trăirile sale dominante din momentul respectiv. Considerăm detaliul ca fiind relevant pentru că atît Dostoievski, cît și Salinger, își plasează eroii în situații pe care le-am numi, „de tip experimental”, pentru a evidenția reflexe psihologice sau, uneori, trăiri specifice pulsiunii de moarte, despre care psihanaliza freudiană a susținut că se află în egală măsură cu pulsiunea vieții, în partea inconștientă a existenței umane. După cum amintea, la noi, și Vasile Dem. Zamfirescu, din perspectiva relațiilor sociale, unele persoane „par urmărite de o soartă demonică: binefăcătorii [sînt] părăsiți sistematic, cu ură, de cei care au beneficiat de gratitudinea lor, bărbați la care orice prietenie se sfîrșește prin a fi trădați...” (Zamfirescu, 2001, p. 73).

Parte a aceleiași pulsiuni de moarte, numite de Freud și thanatică, este și ura pe care adolescenții o folosesc ca sistem de protecție în fața unei lumi pe care nu o pot înțelege, încă, pe deplin. Blocați în tipare ideologice și comportamentale, atît Arkadi, cît și Holden se simt în siguranță disprețuind și îndepărtînd astfel toate scenariile incomode. Dovada cea mai bună, în acest sens, vine prin intermediul textului dostoievskian, și a felului în care, la adăpostul urii, eroii își construiesc un univers comod în care sentimentele de frustrare sînt atenuate. În absența filonului creștin, peste care se suprapune uneori personalitatea eroilor, cum ar fi Aleoșa sau Mîșkin, Dostoievski se lasă purtat de imaginarul morbid, aproape cu exclusivitate. Adolescentul, fie că vorbim despre Smerdeakov, fie că ne referim la Arkadi, este asociat unei perioade de criză în care refugiul în sine reprezintă, de multe ori, singura acțiune rămasă disponibilă.

Dintr-o perspectivă psihanalitică am putea emite o ipoteză care să apropie tipologia bastardului de cea construită de Marthe Robert, prin manifestările ei maladive. Crizele lui Smerdeakov, cunoscute de toți cei apropiați și asupra cărora se proiectează cît se poate de concret spectrul minciunii pentru a manipula și ascunde propriile intenții criminale, are un corespondent, dacă ar fi să privim înapoi, cronologic, în literatura dostoievskiană, în boala care îl afectează pe Arkadi după umilirea publică și respingerea sa dintrun cerc de jucători la ruletă. Astfel, el este acuzat de furt sau că trişează, respingîndu-i-se în mod direct calitatea morală: „Așa-i cînd nu se mai cere nici o recomandație! Cine-i dumnealui?! Cine l-a introdus?” (Dostoievski, 2019, p. 328). Și, mai mult, când se invocă batjocoritor chiar descendența sa, tînărul jucător intră pe calea alienării, bine cunoscută tuturor personajelor dostoievskiene respinse social. Alungat fără menajamente dintr-un grup din care ar fi vrut sa facă parte, domnul Goliadkin, protagonistul din Dublul, rătăcește pe străzi afectat de brutala reacție a oamenilor considerați ca făcînd parte din înalta și buna societate. Este elementul declanșator al scindării interioare, metaforă strălucită și care își arată complexitatea, din păcate, mult mai tîrziu, în raport cu întreaga operă a lui Dostoievski. Alungat, așadar, dintr-un cerc în care se simțea în siguranță și, din perspectiva jocului de noroc, egal cu toți ceilalți, Arkadi rătăcește la fel ca mult mai bătrînul Goliadkin. „Am pornit aproape în fugă”, este descris zbuciumul interior al tînărului pus iarăşi în fața scenariului de respingere, lăsat fără singurul suport emoțional, indirect dobîndit prin apartenența la grupul pariorilor,

„ca și cum m-aș fi grăbit să ajung undeva, nici eu nu știam unde [...], nici nu știam dacă voiam să mă duc undeva [...]. Aveam o senzație ciudată: parcă în jurul meu totul, chiar și aerul pe care-1 respiram, era de pe altă planetă [...] Mă înstrăinasem de toate, dintr-odată, nimic nu mai era al meu" (Dostoievski, 2019, p. 329).

Condus pe străzile pustii ale orașului de sentimental acut al respingerii, pus în faţa unui grup în care nu a găsit nici o formă de suport, nici măcar din partea celor de la care s-ar fi așteptat adolescentul să 
primească o formă de recunoaștere, „spune-le că mă cunoști, spune-le ce fel de om sînt!” (Dostoievski, 2019, p. 328), Arkadi se lasă cuprins în întregime de pulsiunea de moarte, prin urmare, de o anumită psihologie a distrugerii în care vrea să dea foc unei cantități importante de lemn: „Știu doar atît că deodată m-a cuprins o dorință irezistibilă [...]. Pe un ger ca ăsta focul se întinde repede...” (Dostoievski, 2019, p. 331). Prin urmare, abia într-un asemenea context, creat anterior de geniul scriitorului rus, putem vedea mai clar felul în care Salinger își proiectează eroul, atins de reflexe și marcat de atitudini despre care nu ni se spune aproape nimic. Fără să poposească în anatomia trăirilor umane, așa cum face Dostoievski, sondînd permanent în eroii săi pentru a arăta adevărata lor natură, Salinger se limitează la descrieri care, chiar laconice fiind, se suprapun perfect peste tipologia psihologică dostoievskiană. Cu același sentiment al respingerii sociale, la care contribuie cît se poate de generos, după cum o face și Arkadi, Holden rătăcește cuprins de trăiri pe care nu ne-am grăbi să le asociem, în mod automat, vîrstei. Simțindu-se ,îngrozitor de singur și de trist” (Salinger, 2001, p. 188), se lasă purtat de trăirea dominantă: „Central Park nu era prea departe și, cum n-aveam unde să mă duc - nici măcar nu știam încă unde o să dorm -, m-am dus”. Fără să se raporteze la un orizont financiar, esențial și pentru prima parte a romanului Adolescentul, unde Arkadi este stăpînit de o idee secretă, repede și cu un minim efort intuită atunci cînd vine vorba despre ea, comportamentul specific jucătorului lipsit de voință și de luciditate în faţa ruletei se instalează tot prin intermediul pulsiunii de moarte, ca motor principal al tuturor acțiunilor protagonistului. În sine, natura ideii sale, „să devin un Rothschild” (Dostoievski, 2019, p. 80), atît de ușor intuită de tatăl care nu l-a recunoscut, Versilov, „...părerea mea e că el vrea... să devină un Rothschild, sau ceva asemănător, și să se retragă în propria lui măreție...” (p. 110), sugerează o superficialitate despre care tînărul erou nici măcar nu are intuiția existenței ei.

Relația ură - pulsiunea de moarte, la Dostoievski, reprezintă, chiar dacă discutăm despre romanul cel mai puțin apreciat dintre marile romane ale scriitorului rus, prilejul unui discurs concentrat, analitic privind psihologia unui individ aflat într-un moment de criză din existența sa. Plasate întotdeauna la extreme, tipologiile umane dostoievskiene se suprapun peste prototipuri umane universale, iar autenticitatea pulsiunii de moarte, atît de vizibile în întreaga operă, este ancorată în biografia plină de dramatism a scriitorului. În vreme ce pe unii tineri ai operei dostoievskiene, ca Mîșkin sau Aleoșa, orizontul creștin ii pune în evidență mai degrabă ca pe martiri, într-o permanentă pendulare faţă de cele mai importante concepte ale umanității (cum ar fi binele, frumusețea sau adevărul), absența registrului spiritual lasă loc unei morbidități libere să se manifeste și, adesea, imposibil de stăpînit. Părți importante ale tipologiei antieroului se manifestă în cazul personajului central din Adolescentul, unde slăbiciunea trupească, dar pe alocuri inclusiv morală a protaginistului din subterană par să se fi imprimat și asupra tînărului. Am putea spune, pe de altă parte, că o temeinică și veritabilă înțelegere a conceptului de antierou la Dostoievski poate fi discutată doar prin referiri la întreaga operă a scriitorului rus. „Am o fire ciudată”, mărturisește Arkadi, „sînt în stare să prind ură pe locuri și pe lucruri, de parcă ar fi oameni” (Dostoievski, 2019, p. 141), iar pentru ca asemănarea cu eroul subteranei să fie și mai frapantă, putem citi mai departe despre lașitatea tînărului: „,...n-am ieșit din ascunzătoare, fiindcă n-am îndrăznit; de frică, m-am purtat ca un laș, ca un ticălos" (p. 155). Ca pulsiune de distrugere, ura pe care o resimte Arkadi față de obiecte, dar și felul în care Holden uită, ca printr-un act ratat susținut de același sentiment, toate echipamentele pentru competiția de floretă, au o dimensiune inconștientă veritabilă, aşa cum discută și reputatul psiholog Leonard Gavriliu referindu-se la ură prin intermediul relației promordiale „a subiectului cu obiectele reale din lumea exterioară” (Chemama, 1997, p. 366), dar și la incidențele sociale specifice, imposibil de evitat.

Inabilitatea tînărului din romanul lui Dostoievski de a-și cristaliza opinii și reprezentări ale unor concepte complexe poate fi urmărită pe întregul parcurs al textului. Atras de forțe opuse, cînd spre iubire și compasiune, cînd spre dispreț și ură, Arkadi este proiectat aproape în sens pedagogic, fără mascarea sau cosmetizarea nici unei emoții resimțite. În fața mamei sale, tînărul este la fel de incapabil să-și controleze procesul sinuos de maturizare și recunoaște cu un cinism care sugerează aceeaşi imaturitate că „cel mai mult o chinuiam pe mama” (Dostoievski, 2019, p. 348). Necondiționat tolerat și iubit, cel puțin de imagoul matern, Arkadi este prins între aceleași reacții opuse. În lacrimi, dar consolat de mama sa, acceptă 
manifestările de tandrețe și iubire, dar răspunsul arată același zbucium specific procesului de maturizare: „....s-a aplecat spre mine și a început să mă sărute. Mi-am călcat pe inimă și am lăsat-o, deși în clipa aceea am urît-o cu adevărat” (p. 349).

Vom observa, aşadar, că singura și cea mai apropiată emoție față de iubire rămîne ura. În spatele ei se ascunde Arkadi, dar și Holden, în manieră aproape identică, pentru a se refugia din fața unei lumi a cărei legi și reguli rămîn, încă, greu de interiorizat. Ura este cea care domină în registrul emoţional al personajelor dostoievskiene, fiind și prima reacție față de cele mai multe dintre contextele care-i provoacă neplăcere sau doar frustrare adolescentului. Pulsiunea de moarte de care este dominat Arkadi, după cum am afirmat, este vizibilă în graba eroului de a-și asuma o trăire atît de apropiată de iubire. De pildă, „în inimă mi s-a aprins o ură cumplită” (Dostoievski, 2019, p. 365) sau „urîndu-l din toată inima în momentul acela" (p. 431), reprezintă reacții identice, de apărare, în contexte sociale diferite.

Holden, pe de altă parte, reprezintă o veritabilă descriere a tipologiei inadaptatului care se refugiază în cuvinte despre care crede că sînt realități. Pe o întindere nu atît de generoasă ca la Dostoievski, Salinger folosește cuvîntul „ură” sau derivatele sale de peste cincizeci de ori. Holden Caulfield, cu toate că traducerea în limba română nu urmărește acest detaliu și alege de multe ori să înlocuiască „ură” cu alte forme, care sugerează fie frustrare, fie neplăcere sau pur și simplu o formă de respingere, este pentru literatura americană un reper de neocolit atunci cînd se discută despre antierou și trăsăturile acestuia. Pe aceeași direcție deschisă de tipologia dostoievskiană, Holden se grăbește să urască și să-şi manifeste ura față de toți cei dispuși să-l asculte sau faţă de elemente ale lumii pe care încearcă să o descopere. De pildă, Salinger construiește tipologia adolescentului din mici detalii relevante, cum ar fi atitudinea acestuia față de cinematograf, „If there's one thing I hate, it's the movies” (Salinger, 1951, p. 4), în vreme ce traducerea în limba română se axează, oarecum pe bună dreptate, pe un sentiment cu totul diferit: „Dacă e ceva de care mi-e silă sînt filmele" (Salinger, 2001, p. 4).

În alt context, cel al exmatriculării, Holden vorbește despre viitoarea și apropiata sa plecare, meditînd asupra despărțirii de loc și de oameni, „I mean I’ve left schools and places I didn't even know I was leaving them. I hate that” (Salinger, 1951, p. 7), în vreme ce traducerea în limba română alege pentru „hate”, „nu pot să sufăr asta” (Salinger, 2001, p. 9). Exemplele ar putea continua. „Grand. There's a word I really hate” (Salinger, 1951, p. 14), gîndește adolescentul, ascultîndu-şi profesorul, tradus cu ,...un cuvînt pe care nu pot să-l sufăr" (Salinger, 2001, p. 15). Există totuși dovezi care arată, dincolo de acuratețea traducerii, o intimă înțelegere a universului în care trăiește eroul american. Pus în fața propriului eseu, pe care profesorul i-l citește, tînărul reacționează în singurul fel cunoscut, disponibil: „Se opri și puse jos lucrarea. Începusem să-l urăsc" (Salinger, 2001, p. 18). Eroul din De veghe în lanul de secară urăște unele dealuri urbane, unele răspunsuri prea generale din partea interlocutorilor, să doarmă atunci cînd nu se simte obosit, conflictele cu pumnii sau pe unii dintre colegii săi. Pe cît de generală și de extinsă pare acțiunea sentimentului, pe atît este de superficial, ca mai toate celelalte reacții și atitudini, în afara fantasmei de a salva copiii care se joacă la marginea prăpastiei. Ura lui Holden, ca și cea resimțită sub forme diferite de Arkadi, nu-l plasează întrun context de incompatibilitate cu lumea, cu oamenii sau chiar cu elementele asupra cărora proiectează sentimentul. Mai degrabă în registrul infantil, decît în cel adult, surprinși în momente de metamorfoză și de zbucium, între cele două orizonturi de existență, eroii se grăbesc să respingă scenarii sau oameni față de care simt frustrare. Strălucirea celor doi scriitori, capabili să joace cu deplină autenticitate rolul tînărului frustrat și care din reflex respinge mental, pasiv, deci cu o minimă agresivitate (în contextul în care ura sugerează pasiune activă și, de cele mai multe ori, manifestă), tot ceea ce nu-i este pe plac (o altă trăsătură care surprinde un orizont pueril, incapabil să gestioneze emoțiile negative sau scenariile provocatoare de frustrare), devine vizibilă prin micile detalii din viața interioară a celor doi eroi.

\section{Concluzii}

Sîntem, așadar, în fața a două tipologii psihologice similare, despărțite de timp, dar și provenind din spații culturale cît se poate de diferite. Arkadi și Holden fac parte din categoria inadaptaţilor care găsesc în ură 
un refugiu de cîte ori contextul social le provoacă frustrare. Opunîndu-se egoist, ca parte a unui reflex infantil, oricărei senzații de neplăcere, de tipul celor atît de frecvent resimțite de eroi, tristețea este, de obicei, sentimentul la care ajung cei doi protagoniști. Copleșiți de ea și, într-o măsură vizibilă, anesteziați în capacitatea de a percepe lumea, Arkadi și Holden rămîn în literatura universală ca prototipuri. Relația dintre ură și tristețe, extrem de subtilă în cele două opere literare, devine din ce în ce mai vizibilă pe măsură ce se construiește o imagine a paternității absente și în fața căreia protagoniștii nu pot rămîne indiferenți. Blocat în prejudecata socială, care ajunge să-i altereze comportamentele într-o manieră masochistă (adolescentul exercită o formă de supunere față de unii colegi, dusă la extrem, în paralel cu sentimentele de dispreț pentru ei), Arkadi este preocupat permanent, de fapt, dincolo de țesătura intrigilor, de descoperirea propriului său tată, ca prezență fizică, umană. În căutarea propriei identităţi, hiperbolizînd de obicei imagini sau povești în legătură cu tatăl său natural, eroul alunecă adesea în conflicte interioare, cu atît mai mult cu cît devine clar, spre finalul romanului, că fiul și tatăl iubesc aceeași femeie, miză mult prea previzibilă pentru complexitatea specifică literaturii lui Dostoievski.

În căutarea figurii paterne se află și Holden. Acesta pare preocupat de găsirea unei figuri paterne în profesorii pe care îi vizitează și față de care se poartă mai mult ca un fiu, decît ca un elev proaspăt exmatriculat. Dicționarul de psihanaliză pune ura în relație directă cu figura paternă prin dezbătuta ipoteză oedipală: ,...ura tatălui stă la originea legii simbolice a interdicției, adică a legăturii sociale” (Chemama, 1997, p. 367). Conflictul lui Holden cu autoritatea, pe acelaşi filon psihanalitic, evocă un tipar social. Astfel, sentimentul de incompatibilitate cu școlile prin care trece, cu același rezultat - exmatricularea, conflictele interioare, sau deschise, cu ceilalți colegi, sentimentele acute de singurătate și de tristețe, care anunță abandonul, dar și nevoia sa de companie fizică, de a se afla alături de alți oameni (inițiază un dialog și o invitație nepotrivită cu mama unui fost coleg, invită chiar și un taximetrist să petreacă timp împreună) evocă aceeaşi figură paternă față de care tînărul are sentimente inconștiente. Finalul romanului lui Salinger îl plasează pe Holden Caulfield pe ultima treaptă a metamorfozei interioare. Decis să-și abandoneze familia și să plece pentru totdeauna de acasă, blocat într-o ură care acoperă cea mai mare parte a relațiilor sale sociale, Holden se răzgîndește, sub influența singurei persoane care pare să fi păstrat un ascendent asupra credințelor și sentimentelor sale - sora sa mai mică. „Greșiţi în povestea asta cu urîtul”, afirmă spre final eroul (stabilind că ura a reprezentat pentru întregul său discurs și orizont simbolic o realitate), pus în fața deciziei personale de a pleca și a suferinței provocate surorii sale, „vreau să spun, în legătură cu faptul c-am să ajung să urăsc toți fotbaliștii și tot. Zău că greșiți [...]. Îi uram eu cîteodată - e adevărat, dar nu ținea prea mult" (Salinger, 2001, p. 226).

Pe marginea prăpastiei, măcar pentru sora sa, rămîne Holden, aşa cum și-a imaginat. Depășind momentul de criză și eșecul la încă un colegiu, alături de sora sa, murat de ploaie, simte pentru prima dată, clar, altceva decît ură sau tristețe: „Mă simțeam deodată nemaipomenit de fericit, uitîndu-mă la Phoebe cum se tot învîrte în călușei. Și, dacă vreți să știti, era cît pe-aci să strig de fericire” (Salinger, 2001, p. 256).

Ne-am fi așteptat oricum și din partea scriiturii dostoievskiene la un deznodămînt care să ridice eroii, atît de minuțios sondați și prezentați, în cele mai intime reacții și reflexe, oferindu-le, în cele din urmă, cadrul potrivit pentru a depăși episodul de criză. Salinger, pe de altă parte, reprezentînd un cu totul alt spațiu cultural, își declară fidelitatea față de principiul cathartic, eliberîndu-și eroul de resentimente și propulsîndu-l în timp, pentru multe alte nenumărate generații de lectori.

\section{Bibliografie}

Chemama, R. (ed.) (1997). Dicționar de psihanaliză. Semnificații. Concepte. Mateme, traducere, avanprefață și completări privind psihanaliza în România de dr. Leonard Gavriliu, Editura Univers Enciclopedic, București.

Daniel, C. \& Acsan, I. (eds) (1981). Povestirea lui Ghilgameş, în Tăblițele de argilă. Scrieri din Orientul Antic, traducere, prefață, cuvinte înainte și note de Constantin Daniel și Ion Acsan, Editura Minerva, București.

Dostoievski, F.M. (1962). Idiotul, roman în patru părți, în românește de Tamara și Nicolae Gane, prefață de G. Fridlender, Editura pentru Literatură Universală, București.

Dostoievski, F.M. (1993). Frații Karamazov, roman în patru părți şi epilog, vol. 2, traducere de Ovidiu Constantinescu și Isabella Dumbravă, Editura Cartea Românească, București. 
Dostoievski, F.M. (2019). Adolescentul, traducere din limba rusă de Emma Beniuc, Editura Art, București.

Robert, M. (1983). Romanul începuturilor și începuturile romanului, traducere de Paula Voicu-Dohotaru, Editura Univers, Bucuresti.

Salinger, J.D. (1951). The Catcher in the Rye, Little, Brown and Company, Boston, [online].

Salinger, J.D. (2001). De veghe în lanul de secară, traducere și note de Catinca Ralea și Lucian Bratu, Editura Polirom, Iași.

Zamfirescu, V.D. (2001). Filosofia inconștientului, Editura Trei, București. 